\title{
From Welfare State to Optimal Size of Government: A Paradigm Shift for Public Policy
}

\author{
Patrick J. Caragata
}

$\mathrm{N}$ EW ZEALAND has climbed a tax mountain for most of the 20th century. In 1921 the total tax take exceeded 15 per cent of GDP; in 1941 it exceeded 20 per cent; in 194325 per cent; and in 198030 per cent. In 1990 it reached a historic peak of 36 per cent, falling back to 34 per cent in 1997.

This tax mountain is the creation of rising government expenditure. In 197374 , government expenditure accounted for 28 per cent of GDP. After 1975, it generally remained over 38 per cent and peaked in 1986-87 at 44.2 per cent. Much of this increase reflected the rising cost of social transfers, which jumped from 12 per cent of total government expenditures in the early 1970s to a peak of around 22 per cent in 1989.

During 1950-75, interest on the public debt averaged 2.4 per cent of GDP a year. It rose to 3.2 per cent in $1975-79,5$ per cent in $1980-84$, and 7.2 per cent in 1985-89. It peaked at 8 per cent of GDP (and 20.7 per cent of government expenditure) in 1987-88. This level was comparable to the early years of World War II (1940-42), when interest payments consumed 22.4 per cent of total expenditures. The gross public debt itself was 40.5 per cent of GDP in 1973-74; within five years, it reached 53 per cent of GDP. At its peak in 1986-87, the gross public debt reached 77.2 per cent of GDP.

Even in the late 1980s, after the reforms of Roger Douglas, the Minister of Finance, government expenditure did not fall below 38 per cent of GDP, ten percentage points above the $1973-74$ level. The ratio remained at 38 per cent for the first two years of the Bolger National government (1991-92), reflecting the need to cushion those most affected by the structural adjustment of the economy and high debt service payments (Caragata, 1997:55-70).

This huge increase in the role of government, from 28 per cent to 44 per cent of GDP in the 13 years from 1973-74 to 1986-87, was not planned; nor was it subjected to any cost-benefit analysis or risk assessment of its potential impact on the

\footnotetext{
${ }^{1}$ This estimate excludes local government taxes and the Accident Compensation Commission levy that together account for 3 per cent of GDP.
}

Patrick Caragata is Managing Director of McCallum Petterson Financial Diagnostics Ltd, Wellington. In 1991-97 he was Chief Tax Policy Adviser and then Special Adviser, Taxation Economics, with New Zealand's Inland Revenue. 
economy. Rather, it reflected a dominant welfare-state paradigm about the role of government that has guided political thinking for over 50 years but is now beginning to lose its grip.

The main aim of this article is to summarise some recent research findings on the rising paradigm on the optimal size of government that is replacing the welfarist paradigm.

\section{The Rise and Fall of the Welfare State Paradigm}

As understood by Thomas Kuhn (1962/1970) in his study of scientific revolutions, paradigms are frameworks of concepts and assumptions that organise and explain experience. Over time, anomalies accumulate that become too difficult for the reigning paradigm to resolve; eventually it breaks down and is replaced by a new paradigm.

J. M. Keynes is a central figure in the emergence of the welfare-state paradigm, which he elaborated by rejecting the two extremes of state socialism and laissez faire and defining a middle ground between them. This new paradigm sanctioned the enlargement of the role of government' for the purpose of correcting deficient demand (Keynes, 1936:380-1). The problem with the new paradigm was that it consisted of the middle ground between two extreme options in an extreme case: the Great Depression. After the Western economies recovered, growing liberalisation of international trade and (later) of capital flows challenged the role and competence of government's economic management. Eventually, the welfare state reached its limit in the $1990 \mathrm{~s}$, when fiscal deficits and public debt grew to proportions that destroyed government's ability to intervene effectively: additional government spending raises interest rates, which negates any stimulus it provides to demand.

The welfare state was seen as a political and social panacea by the post-war generation (the 'baby-boomers') who were the first beneficiaries of the full range of its services in health, education and social security, as well as by an older generation that benefited in particular from the old-age pension. Even as it was being stretched far beyond its original purpose and problem-solving capabilities, it became closely identified with democracy itself. But then it started to undermine welfare by weakening the values and protective power of the central institutions of civil society: the family, the churches, and the voluntary associations.

This problem has led Sandel (1996:3) to identify the two principal causes of what he calls Democracy's Discontent.

One is the fear that, individually, and collectively, we are losing control of the forces that govern our lives. The other is the sense that, from family to neighbourhood to nation, the moral fabric of community is unravelling around us. These two fears - for the loss of self-government and the erosion of community - together define the anxiety of the age. It is anxiety that the prevailing political agenda has failed to answer or even address. 
Sandel (1996:351) ends his book by observing that 'the hope of our time rests ... with those who can summon the conviction and restraint to make sense of our condition and repair civic life on which democracy depends'.

Yet despite his valuable insights, Sandel fails to see the connection between large, intrusive government and the loss of autonomy and the erosion of community. As taxes rise and the government gets bigger, it tends to crowd out the institutions of civil society by pre-empting their roles and undermining individual selfreliance. This argument was made by Alexis de Tocqueville (1835/1945:116) over 150 years ago, in an astonishing premonition not only of the rise of the welfare state but also of the problems that have brought it into question:

The more [government] stands in the place of associations, the more will individuals, losing the notion of combining together, require its assistance: these are causes and effects that unceasingly create each other ... The morals and the intelligence of a democratic people would be as much endangered as its business and manufactures if the government ever wholly usurped the place of private companies.

Government has a role to play in assisting those in genuine need. But should as many as a fifth of New Zealanders of working age, and nearly a third of New Zealand's children, be dependent on state welfare (Cox, 1998:27)?

\section{Paradigm Shift}

There are numerous signs that the tide of big government is receding. Interest is growing in the high compliance costs of government. The appearance of Osborne and Gaebler's book Reinventing Government (1992) suggests that governments are trying to increase the efficiency of public spending. In his 1996 State of the Union Address, US President Bill Clinton announced that the 'era of big government is over'. In the late 1990s, there is talk, and even some action, in the United Kingdom, the United States, Australia and New Zealand on replacing welfare handouts with 'workfare'.

The principal reason for this disillusionment with big government is that, if it grows beyond a certain point, the public sector reduces welfare rather than increases it. In his overall analysis of the link between taxes and growth, Gerald Scully, a leading pioneer in the field of the optimal size of government, has observed that:

Economic theory suggests that up to some level, government expenditures increase the productivity of private economic resources. The provision of national defence and a judicial system protect private property and individual rights. Other publicly provided goods, such as infrastructure, also enhance private productivity. Thus, up to some point, government expenditure acts as a positive externality on private economic activity ... Beyond some optimal size of government, increased taxation acts as a negative externality on the private sector. (Scully, 1996a:4-5) 
The new paradigm therefore centres around the question: what is the optimal size of government? Martin Feldstein (1996:26) has recently argued that 'the central public finance question facing any country is the appropriate level of spending and therefore of taxes'. A considerable literature has emerged that attempts to answer that question. Clark (1945), inspired by Keynes, suggested that where the objective is to minimise inflation and stabilise the exchange rate, the optimal effective tax rate is likely to be around 25 per cent of national income (equivalent to about 21 per cent of GDP in New Zealand). More recently, Peden (1991:168-9) has found that over the period 1929-86 US government expenditure up to 17 per cent of GNP improved the productivity performance of the economy, but expenditures above that level reduced 'the growth of productivity'.

In its 1997 World Development Report, the World Bank (1997:168-71) emphasises the value of an 'effective state' that facilitates rather than impedes higher levels of economic performance. Its cross-country study examining the impact of 14 independent variables on the growth in GDP per head concludes that the size of government (measured by government consumption's share of GDP) has an important and consistently negative impact on the standard of living (though it did not search for an optimal level of tax or expenditure relative to GDP).

Tanzi and Schuknecht (1997) compare the economic performance (growth rates, gross fixed capital formation, inflation, unemployment, and debt) and social performance (life expectancy, infant mortality, education and income distribution) of 17 small, medium and large OECD countries. They conclude that 'there is no evidence' that countries with big governments out-perform the countries with medium and small governments. When government expenditure rises much above 30 per cent of GDP, there are diminishing returns to the social gain from public spending (Tanzi \& Schuknecht, 1997:167).

Finally, a recent OECD report has concluded that:

up to one-third of the growth deceleration in the OECD (from around 5 per cent in 1965-73 to around 2 per cent in 1989-95) would be explained by higher taxes. In some European countries, tax burdens increased much more dramatically than the OECD average, which would imply correspondingly larger effects on their growth rates. (Leibfritz, Thornton \& Bibbee, 1997:49)

\section{Optimal Tax Levels for Growth and Employment}

Caragata (1998) presents the final report of the New Zealand Inland Revenue's Taxation Economics Group. One of the principal aims of our research project during 1994-97 was to determine the level of tax that is optimal with respect to two simultaneous objectives: (i) maximising economic growth and employment; and (ii) efficiently minimising tax evasion. Our approach was to estimate a range for the ratio of tax to GDP and the tax mix (direct and indirect tax relative to GDP) that would maximise economic growth and employment and efficiently minimise tax evasion. 
For New Zealand, we concluded that the optimal level of total tax (the level at which economic growth is maximised) is probably located between 15 per cent and 25 per cent of GDP. We used five separate sets of models, with three research teams. This multiple-methods approach was designed to provide reassurance about the quality of the results.

Scully (1996a) uses a non-linear Cobb-Douglas production function model that combines analysis of the tax mix, the ratio of tax to GDP and the rate of real economic growth. The model can also be used to estimate the tax burden and tax mix that maximise employment growth and economic growth, and minimise deadweight loss. The model involves an economy with a public sector and a private sector, exhibiting constant returns. The latter feature of the model is supported statistically by the data. With this constraint, and using the empirical estimates for the model's parameters, positive growth paths emerge. The empirical basis of the model is crucial: misleading results could be obtained if arbitrary values were assigned to the parameters. The rate of growth is a function of the tax level, and the model facilitates a calculation of the value of the latter rate that maximises output growth.

Scully (1996a) estimates that New Zealand loses two percentage points of growth a year because total taxes were higher than 20 per cent of GDP. His model yields a growth-maximising tax level range, covering the years 1927-94, of 16.4 per cent to 23 per cent, for an average of 19.7 per cent of GDP. Scully also finds that the growth-maximising tax levels for some other countries are consistent with those for New Zealand.

Research by Scully (1996c) covering the period 1951-94 in New Zealand indicates that a one percentage point increase in the ratio of tax to GDP appears to have its strongest impact in labour markets on employment growth, although the impacts on labour force participation and the unemployment rate are also strong. $A$ one percentage point increase in the ratio of tax to GDP in New Zealand lowers employment growth by over 42,470 workers, decreases labour force participation by 11,900 workers and increases the unemployment rate by about 15,900. The optimal tax level for maximising employment is about 20 per cent of GDP.

\section{Deadweight Loss Estimates}

Ballard and Fullerton (1992:118-19) note that deadweight loss analysis has typically ignored the effects of administration costs and compliance costs. By contrast, the work for New Zealand's Inland Revenue by Scully (1996a), Caragata and Small

\footnotetext{
${ }^{2}$ For the period 1927-88, the growth-maximising tax level for the UK was 25.2 per cent; the optimal level was lower for Denmark (18.5 per cent), Finland (18.9 per cent), Italy (20.1 per cent), and Sweden (16.6 per cent). The average across all the countries was estimated to be 19.9 per cent. In another paper on the growth-maximising tax level for the US, Scully (1995) estimates that, over the period 1929-89, real growth rates in the US decline when the ratio of tax to GDP rises beyond about 23 per cent. Earlier, Scully (1991:2) showed that for 103 countries for the period 1960-80 'on average, countries reach their maximum economic growth rates when they take no more than 19.3 percent of GDP in taxes'.
} 
(1996a) and Branson and Lovell (1997) picks up these effects in their analysis of dynamic deadweight loss.

Branson and Lovell (1997), using a two-tier model employing both econometrics and data envelopment analysis, conclude that for the period 1946-95, on average, economic output fell short of its annual potential by 17 per cent because taxes were at 35 per cent of GDP rather than a growth-maximising rate of 22.5 per cent of GDP. This 'deadweight loss' is the gap between actual and potential economic performance arising from taxes. ${ }^{3}$ Branson and Lovell conclude that if deadweight losses were added to the existing tax burden, the effective tax rate would be 51 per cent of GDP, not 35 per cent.

Scully (1996a) estimates that, for each dollar of tax in New Zealand, there is a long-run cost to the economy of about $\$ 2.70$. The magnitude of these results is confirmed by Caragata and Small (1996a) and anticipated by Usher (1991), Bird (1991) and Feldstein (1995). These magnitudes are also consistent with the cumulative aggregation of output losses imposed by government intervention anticipated by Mancur Olson (1996). Thus, a cost-benefit analysis approach to tax policy-making would operate on the assumption that, for a dollar of government spending to be justified, it would have to produce a long-run benefit of at least about $\$ 2.70$.

\section{Optimal Tax Levels for Efficiently Reducing Tax Evasion}

Another approach to estimating the optimal size of the government is to determine the tax level that efficiently minimises the hidden economy and tax evasion. Twenty-five ago, when OECD countries' tax levels were averaging about 30 per cent of GDP, various studies estimated that their hidden economies ranged from 7 per cent to 16 per cent of GDP. ${ }^{4}$ Thus, an average of about 10 per cent of the income of OECD countries was unreported for tax purposes.

Currently, with the average ratio of tax to GDP of about 38 per cent, many countries have underground economies ranging from 10 per cent to 25 per cent of GDP, with an average at about 16 per cent. That is to say, while their average tax burden has gone up by 30 per cent since 1970, their hidden economies grew by about 60 per cent. For New Zealand, the tax burden rose by 35 per cent between 1971 and 1994, while the hidden economy jumped from 7 per cent of GDP in

\footnotetext{
${ }^{3}$ This output efficiency approach is different from the conventional approach which emphasises the static allocative efliciency effects of tax. Thus, Diewert and Lawrence $(1994,1995)$ estimate deadweight losses in New Zealand of 18c per dollar of tax on labour, and 14c per dollar of tax on consumption, using a static model with no confidence intervals. For an econometric critique of these results, see Small (1995). 4

Giles (1996:7) summarises the hidden economy estimates for the 1970s. Recent research undertaken by Friedrich Schneider (1997) estimates the hidden economy at about 7 per cent of GDP in Switzerland and Austria, 12-15 per cent in Japan, the US, Britain, Australia the Netherlands, Germany, France, Canada, Ireland, Denmark, Norway and Sweden, and 18-26 per cent in Belgium, Spain and Italy. See also Aigner et al. (1988).
} 
1970 to 11.3 per cent in 1994, an increase of 63 per cent (Giles, 1996). Thus, New Zealand's tax burden and hidden economy have been growing as fast as, or faster than, the OECD average. This raises the question of what ratio of total tax to GDP efficiently minimises the hidden economy and related tax evasion.

Five models developed by Giles (1996) show that the hidden economy responds more to tax than to inflation and government regulation, and that the hidden economy was pro-cyclical rather than counter-cyclical. In New Zealand, the hidden economy is currently around 11 per cent of GDP and tax evasion is estimated at about $\$ 3.2$ billion a year. As taxes are reduced, the hidden economy will shrink. But if taxes are driven to zero, the hidden economy will still be about 4 per cent of GDP, representing the hard core of criminal activity in the hidden economy that is driven by factors other than tax (Giles \& Caragata, 1996).

Caragata \& Giles (1996) develop a model for New Zealand estimating an efficient tax evasion-minimising optimal tax level of 21 per cent of GDP. This provides further corroboration that the optimal tax level is close to 20 per cent of GDP. We find that a mix of 33 per cent direct tax and 67 per cent indirect tax would most efficiently minimise the size of the hidden economy and tax evasion. We conclude that if the tax department adopts scientific audit selection, ${ }^{5}$ there would be significant tax revenue gains and significant savings in terms of administrative efficiency for the tax department and compliance cost savings for business.

\section{The Optimal Tax Mix}

Two models that we developed for New Zealand with a growth-maximisation objective favour a tax mix that emphasises direct taxes. Another model with a similar objective emphasises indirect taxes. A fourth model with an objective of minimising tax evasion emphasises indirect taxes.

All the models indicate that the total tax burden is far more important than the tax mix in its impact on economic growth and tax evasion. Branson and Lovell (1997) conclude that the level of tax is six times more important than the tax mix in influencing growth. Scully (1996b) concludes that a mix of 57 per cent direct tax and 4.3 per cent indirect tax would maximise economic growth at a tax:GDP ratio of 20 per cent. Branson and Lovell (1997) conclude that, on average, a mix of 65 per cent direct tax and 35 per cent indirect is optimal for promoting economic growth in New Zealand at an average optimal tax:GDP ratio of 23 per cent.

Caragata and Small's (1996b) non-linear model estimates that, with a ratio of tax to GDP of 20 per cent, tax policy would most accelerate economic growth when the tax mix is 28 per cent direct tax and 72 per cent indirect. This model finds that the relationship between growth and direct taxes is always negative: which implies that a tax mix of zero direct taxes and 100 per cent indirect taxes would potentially maxi-

\footnotetext{
${ }^{5}$ Scientific audit selection ranks all taxpayers from lowest to highest risk and permits rational audit selection. This approach offers the prospect of significantly reducing audit compliance costs of firms which are typically compliant (by diverting audits to higher-risk firms), and reducing operation costs by permitting an elficient reallocation of audit resources to higher-risk firms.
} 
mise economic growth. However, the Caragata-Small model is not free of measurement error and its conclusions are tentative and subject to caution despite their confirmation of the strong trend in economic theory favouring the abolition of the income tax.

Finally, Caragata \& Giles (1996) find that a mix of 33 per cent direct and 67 per cent indirect would most efficiently minimise the size of the hidden economy and tax evasion.

While both the objectives of maximising economic growth and minimising the hidden economy suggest that the current tax mix favouring direct tax over indirect is less than optimal, it seems that a growth-maximisation objective suggests a frontier mix with a rough balance between the two. Thus, too much weight on indirect taxes in pursuit of reducing the size of the hidden economy could undermine economic growth. More research on these new findings is required.

\section{Implications for Fiscal Policy}

All countries have paid a high and often unseen price (in terms of reduced growth and employment and higher tax evasion) for climbing the tax mountain in pursuit of the objectives of the welfare state. The huge increase in the size of government that occurred mainly between the early 1970 s and the late 1980 s was a failure in economic development and policy management.

The old ideological paradigm of the welfare state is now beginning to give way to the empirically based paradigm of the optimal size of government. How can governments most rapidly incorporate the insights of the new paradigm into its fiscal policies?

Tax policy. The first priority is to cut income taxes so that the total tax burden falls and the tax mix places greater emphasis on consumption tax. Tax cuts have weaker growth effects at higher rates (such as 35 per cent of GDP) than at lower rates (such as 25 per cent of GDP). Tax cuts are also best applied before an economy falls into recession.

Crisis management. There is nothing wrong with counter-cyclical financing and government deficits as long as they occur only in emergencies and for short periods. Keynesian fiscal strategies became discredited because politicians wanted to run deficits even during boom times in order to buy votes.

Universality. End universal welfare benefits, which benefit the rich unnecessarily. Help those who need it. Means test all social services and programmes.

Transparency and accountability. Each year, all efficiency and benchmarking reports produced for government departments and agencies should be made public so that taxpayers can determine if they are obtaining value for money from their taxes. 
Public choice: The public should be given more choice about how to spend their money. Many people who are dissatisfied with government provision of police, education and health services opt for private sector solutions, but cannot avoid paying taxes. Thus, they pay twice for these services when they opt for private provision of such services.

Timing. It took 40-50 years to push the state's share of the economy to its current level. It may take a decade or so to move taxes down to about $22-25$ per cent of GDP, in part because of the need for a smooth transition. It should not be allowed to take much longer than that, because higher economic growth is needed in order to finance the expected increase in spending on health services when the retirement of the baby-boom generation peaks in 2025 .

The culture of public control, or regulatory and intrusive management, that has grown up under the welfare state must be ended and replaced with the culture of public service that respects taxpayers as the shareholders of government. The greater the numbers demanding benefits from government, the greater is the welfare dependency of the population, and the greater the level of government control. The greater the level of control, the less acceptable and the more wasteful are government services likely to be. Reducing taxes helps to encourage less wasteful spending and greater personal responsibility.

The new paradigm of the optimal size of government offers politicians the basis for addressing 'democracy's discontent' by reducing the culture of dependency arising from the intrusive welfare state and promoting self-development and learning as the basis for national re-invigoration and enhanced international competitiveness.

\section{References}

Aigner, D., F. Schneider \& D. Ghosh (1988), 'Me and My Shadow: Estimating the Size of the Hidden Fconomy From Time Series Data', pp. $297-334$ in W. Barnett et al. (eds), Dymamic Econometric Modelling. Proceedings of the Third International Symposium in Economic Theory and Econometrics, Cambridge University Press, Cambridge.

Ballard, C. \& D. Fullerton (1992), 'Distortionary Taxes and the Provision of Public Goods', Journal of Economic Perspectives 6: 117-31.

Bird, R. (1991), 'More Taxing Than Taxes: An Introduction', in R. Bird (ed.), More Taxing Than Taxes, Institute for Contemporary Studies, San Francisco.

Branson, J. \& C. Iovell (1997), A Growth Maximising Tax Burden and Tax Mix for New Zealand, Inland Revenue, Wellington (March) (Working Papers on Monitoring the Health of the Tax System No. 30).

Caragata, P. (1997), The Economic and Compliance Consequences of Taxation: A Report on the Health of the Tax System in New Zealand, Inland Revenue, Wellington. (This report was published under the same title by Kluwer Academic Publishers, Dordrecht, in July 1998.)

Caragata, P. \& D. Giles (1996), Simulating the Relationship Between the Hidden Economy and the Tar Mix in New Zealand, Inland Revenue, Wellington (November) (Working Papers on Monitoring the Health of the Tax System No. 22). 
Caragata, P. \& J. Small (1996a), Tax Burden Effects on Output Growth in New Zealand: A NonLinear Dynamic Model, Inland Revenue, Wellington (December) (Working Papers on Monitoring the Health of the Tax System No. 24).

(1996b), The Tax Burden, The Tax Mix and Output Growth in New Zealand: A Tax Mix Model, Inland Revenue, Wellington (December) (Working Papers on Monitoring the Health of the Tax System No. 25).

Clark, C. (1945), 'Public Finance and Changes in the Value of Money', Economic Journal 55: 371-89.

Cox, J. (1998), Towards Personal Independence and Prosperity: Income Support for Persons of Working Age in New Zealand, New Zealand Business Roundtable, Wellington.

De Tocqueville, A. (1835/1945), Democracy in America, Vol. 2, Addison-Wesley, Reading, Mass.

Diewert, W. \& D. Lawrence (1994), The Marginal Costs of Taxation in New Zealand, Swan Consultants, Canberra.

—_ (1995), 'The Excess Burden of Taxation in New Zealand', Agenda 2: 27-34.

Feldstein, M. (1995), Tax Avoidance and the Deadweight Loss of the Income Tax, National Bureau of Economic Research, Cambridge, Mass. (Working Paper No. 5055).

- (1996), How Big Should Government Be?, National Bureau of Economic Research, Cambridge, Mass. (Working Paper No. 5868).

Giles, D. (1996), Measuring the Size of the Hidden Economy and the Tax Gap in New Zealand: An Econometric Analysis, Inland Revenue, Wellington (December) (Working Papers on Monitoring the Health of the Tax System No. 5 (revised]). (Forthcoming in Empirical Economics.)

- \& P. Caragata (1996), The Learning Path of the Hidden Economy: Tax and Growth Effects in New Zealand, Inland Revenue, Wellington (August) (Working Papers on Monitoring the Health of the Tax System No. 21).

Keynes, J. (1936), The General Theory of Employment Interest and Money, Macmillan, London.

Kuhn, T. (1962/1970), The Structure of Scientific Revolutions, 2nd ed., University of Chicago Press, Chicago.

Leibfritz, W., J. Thornton \& A. Bibbee (1997), Taxation and Economic Performance, OECD, Paris (Economics Department Working Papers No. 176).

Olson, M. 1996, 'Big Bills Left on the Sidewalk: Why Some Nations are Rich, and Others Poor', Journal of Economic Perspectives 10: 3-24.

Osborne, D. \& T. Gaebler (1992), Reinventing Government How the Entrepreneurial Spinit is Transforming the Public Sector, Addison-Wesley, Reading, Mass.

Peden, E. (1991), 'Productivity in the United States and its Relationship to Government Activity: An Analysis of 57 Years, 1929-1986', Public Choice 69: 153-73.

Sandel, M. (1996), Democracy's Discontent: America in Search of a Public Philosophy, Cambridge, Mass. 
Schneider, F. (1997), Empirical Results for the Size of the Shadow Economy of Western European Countries Over Time, Institüt für Volkeswirtschaftslehre, Linz University (March) (Working Paper No. 9710).

Scully, G. (1991), Tax Rates, Tax Revenues and Economic Growth, National Centre for Policy Analysis, Dallas (Policy Report No. 98).

— (1995), 'The "Growth Tax" in the United States', Public Choice 85: 71-80.

(1996a), Taxation and Economic Growth in New Zealand, Inland Revenue, Wellington (March) (Working Papers on Monitoring the Health of the Tax System No. 14). Subsequently published as G. Scully (1996), 'Taxation and Fconomic Growth in New Zealand', Pacific Economic Review 1: 169-77.

— (1996b), The Growth-Maximising Tax Mix in New Zealand, Inland Revenue, Wellington (August) (Working Papers on Monitoring the Health of the Tax System No. 20).

(1996c), Taxation and Employment in New Zealand, Inland Revenue, Wellington (August) (Working Papers on Monitoring the Health of the Tax System No. 23).

Small, J. (1995), The Marginal Costs of Taxation in New Zealand: A Sensitivity Analysis of the Diewert and Lawrence Model, Inland Revenue, Wellington (December) (Working Papers on Monitoring the Health of the Tax System No. 16).

Tanzi, V. \& L. Schuknecht (1997), 'Reconsidering the Fiscal Role of Government: The International Perspective', AEA Papers and Proceedings 87 (2): 164-8.

Usher, D. (1991), 'The Hidden Costs of Public Expenditure', in R. Bird (ed.), More Taxing Than Taxes, Institute for Contemporary Studics, San Francisco.

World Bank (1997), World Development Report: The State in a Changing World, Oxford University Press, New York.

I wish to thank Richard Bird, Anna Heiler, Michael James, Gerald Scully, and two anonymous referees for reviewing an earlier draft of this article. Errors and omissions are mine alone. 